\title{
Functioning of Village Health Sanitation and Nutrition Committees in Punjab: An Appraisal
}

\section{DR SHAIK IFTIKHAR AHMED}

Research Faculty, Population Research Centre, Centre for Research in Rural \& Industrial Development

\section{*Email: msiftikhar@gmail.com}

Received: January 12, 2017 | Revised: February 20, 2017 | Accepted: February 25, 2017

Published Online: March 01, 2017

The Author(s) 2017. This article is published with open access at www.chitkara.edu.in/ Publications

\begin{abstract}
The present study aims to assess the composition of VHSNCs; to assess the functioning of VHSNCs and find out the deviations, if any, from the prescribed framework of guidelines and, to understand awareness of VHSNC members about their roles. The proposed study is based on primary data collected with the help of structured questionnaire. The data was collected from one hundred Village Health Sanitation and Nutrition Committees in Punjab. Four districts of the Punjab state were selected randomly from each direction i.e North, South, East and West. The districts selected were Gurdaspur, Mansa, Mohali and Firozpur from North, South, East and West direction respectively. The study reveals that sampled VHSNCs in Punjab have 12 members per VHSNC. One-fourth of the chairpersons of the VHSNCs in Punjab were illiterate Only 23 per cent of the VHSNCs claimed to have prepared the village health plan. Meetings were organized on monthly basis in only half of the expected meetings per VHSNC. Large number of members was not attending the meetings organised by VHSNCs in Punjab. Majority of the funds received by VHSNCs was utilized for sanitation and cleanliness of the village. Majority of members were not aware about the components and objectives of VHSNC. All members reported that the untied fund is always helpful in solving the issues and problems of the village and the amount of untied fund given to VHSNCs should be increased.
\end{abstract}

\section{INTRODUCTION}

National Health Mission (NHM) seeks to provide accessible, affordable and quality healthcare to the rural population, especially the vulnerable sections. It also seeks to improve the maternal and child health services throughout the country. The NRHM has placed strong emphasis in addressing local issues

Journal of Chemistry, Environmental Sciences and its Applications Vol-3, No-2, March 2017 pp. 101-122 
and its solutions and making it community centric through the involvement of Panchayat Raj Institutions (PRIs). In the process, the responsibility of preparing village health plans, its implementation and monitoring has been entrusted to the Village Health Nutrition and Sanitation Committee (VHNSC) formed at village level. These committees are entrusted with the responsibility of enhancing people's participation in improving healthcare services in the rural areas by increasing awareness about health and health entitlements with special focus on women and children (Sah Pramod Kumar et al 2013, Srivastava et. al. 2016).

The roles of VHSNC include development of the village health plan, monitoring of health activities in the village and having a comprehensive understanding of health related activities. Untied fund is also made available to VHSNC for various health activities including IEC, household survey, preparation of health register, organization of meetings at the village level etc. (Semwal V et al 2013)

The NHM has provided guidelines for the framework, functions and responsibilities of these committees and has provided an 'untied fund' of rupees 10,000 per VHNSC per annum. It is expected that community leaders will participate in the governance and improvement of the health facilities of the area. The untied funds should be utilized with the consensus of the community.

Studies conducted to assess the VHSNC in India indicated that formation of committees and fund utilization was not according to guidelines and there were irregularities with reference to conduct meetings. Punjab implemented NHM in 2005 and the VHSNCs came into existence in 2007. Although VHSNCs were formed in almost all the villages in Punjab since 2007 but their functioning was never assessed. There is a need to ascertain whether there is appropriate understanding among the members of VHNSC about their roles, responsibilities and preparedness and capacities to prepare village health plan and act upon it. Hence, this study was designed to assess the functioning of VHNSCs in Punjab.

\section{AIMS \& OBJECTIVES OF THE STUDY}

The present study aims to assess the composition of VHSNCs; to assess the functioning of VHSNCs and find out the deviations, if any, from the prescribed framework of guidelines and, to understand awareness of VHSNC members about their roles.

\section{METHODOLOGY}

The proposed study is based on primary data collected with the help of structured questionnaire. The data was collected from one hundred Village Health Sanitation and Nutrition Committees in Punjab. Four districts of the 
Punjab state were selected randomly from each direction i.e North, South, East and West.

The districts selected were Gurdaspur, Mansa, Mohali and Firozpur from North, South, East and West direction respectively. On the basis of list of VHSNCs provided by the district authorities, 25 Village Health Sanitation and Nutrition Committees were selected from each selected district at random. Field survey to collect first hand information was carried out from May 2016 to July 2016. Pre designed and pre tested questionnaire was used to capture information regarding functioning of VHSNCs in Punjab.

\section{VILLAGE HEALTH NUTRITION AND SANITATION COMMITTEE IN PUNJAB}

After the implementation of National Rural Health Mission (now named National Health Mission) in Punjab in 2005, Mission Director, NRHM, directed Deputy Commissioners of all districts to constitute Village Health Sanitation Committees vide notification no. 1/70/07-5HB-IV/695 dated 21-10-2007 (Annexure II). The guidelines issued by NRHM were also provided to constitute and register the Village Health Sanitation Committee in Punjab at village level. Later on in November 2013 Mission Director, NRHM, directed Deputy Commissioners and Civil Surgeons of all districts to constitute Village Health Sanitation Committees as per the revised guidelines issued by National Health Mission (Annexure III). The nomenclature of these committees became Village Health Nutrition and Sanitation Committee. At present there are 12,956 registered VHSNCs in Punjab. The districts selected namely Gurdaspur, Mansa, Mohali and Firozpur have 1291, 237, 379 and 815 registered VHSNCs (Table 1). During field survey it was observed that all selected VHSNCs were constituted and registered before 2010 .

Table 1: Village Health Sanitation \& Nutrition Committees in Punjab.

\begin{tabular}{cc}
\hline Name of District & Number of VHSNCs \\
\hline Amritsar & 822 \\
Barnala & 159 \\
Bathinda & 298 \\
Fatehgarh Sahib & 435 \\
Faridkot & 187 \\
Firozpur & $\mathbf{8 1 5}$
\end{tabular}


Ahmed, SI

Fazilka

373

Gurdaspur $\quad 1291$

Pathankot 422

Hoshiarpur 1418

Jalandhar 913

Kapurthala 564

Ludhiana 923

Mansa $\quad 237$

Moga 321

Mukatsar 267

Mohali 379

SBS Nagar $\quad 467$

Patiala 946

Ropar 602

Sangrur $\quad 581$

Tarn Taran 536

Total $\mathbf{1 2 9 5 6}$

Source: Mission Director NHM, Punjab, 2016

\section{COMPOSITION OF VHSNCS IN PUNJAB}

The revised guidelines for formation of VHSNC stated that chairperson of the committee should be lady elected member of Panchayat preferably belonging to Scheduled Caste/marginalised group and should be resident of the village. ASHA should be Member Secretary. Members of VHSNC should be ANM, AWW, ASHA Facilitators, MPHW (M), Elected representative of PRIs, School teachers, members of SHG/NGOs, Ex-service man and persons belonging to weaker section of the society. The ideal number of members of VHSNC should be fifteen. The survey reveals that sampled VHSNCs in Punjab have 1217 members in-total i.e. 12 member per VHSNC (Table 2).

Table 2: Composition of VHSNC Members.

\begin{tabular}{llllll}
\hline \multirow{2}{*}{ Personnel } & $\begin{array}{l}\text { Districts } \\
\text { Mansa }\end{array}$ & Gurdaspur & Firozpur & Mohali & Total \\
\hline ASHA & $51(19.3)$ & $33(9.8)$ & $36(11.0)$ & $42(14.5)$ & $162(13.3)$ \\
ANM & $27(10.2)$ & $25(7.4)$ & $21(6.4)$ & $21(7.3)$ & $94(7.7)$
\end{tabular}




\begin{tabular}{|c|c|c|c|c|c|}
\hline AWW/AWH & $39(14.8)$ & $30(8.9)$ & $29(8.8)$ & $29(10.0)$ & $127(10.4)$ \\
\hline $\begin{array}{l}\text { Elected } \\
\text { Representatives }\end{array}$ & $76(28.8)$ & $84(25.0)$ & $\begin{array}{l}129 \\
(39.3)\end{array}$ & $60(20.8)$ & $349(28.7)$ \\
\hline $\begin{array}{l}\text { Multi Purpose } \\
\text { Health Worker (M) }\end{array}$ & $7(2.7)$ & $17(5.1)$ & - & $14(4.8)$ & $38(3.1)$ \\
\hline In Govt. service & $9(3.4)$ & $17(5.1)$ & $19(5.8)$ & $25(8.7)$ & $70(5.8)$ \\
\hline $\begin{array}{l}\text { Social Worker/ } \\
\text { NGO Members }\end{array}$ & $32(12.1)$ & $105(31.3)$ & $79(24.1)$ & $81(28.0)$ & $297(24.4)$ \\
\hline Retd. Govt. service & $19(7.2)$ & $23(6.8)$ & $13(4.0)$ & $8(2.8)$ & $63(5.2)$ \\
\hline Pharmacist / doctor & $4(1.5)$ & - & $1(0.3)$ & - & $5(0.4)$ \\
\hline Dai & - & $2(0.6)$ & $1(0.3)$ & $2(0.7)$ & $5(0.4)$ \\
\hline Total & $\begin{array}{l}264 \\
(100.0)\end{array}$ & $\begin{array}{l}336 \\
(100.0)\end{array}$ & $\begin{array}{l}328 \\
(100.0)\end{array}$ & $\begin{array}{l}289 \\
(100.0)\end{array}$ & $\begin{array}{l}1217 \\
(100.0)\end{array}$ \\
\hline
\end{tabular}

Functioning of Village Health

Sanitation and Nutrition Committees in Punjab: An

Appraisal

The average number of members per VHSNC in district Mansa and Mohali is 11 and in district Gurdaspur and Firozpur it is 13. Among the members 28.7 percent are elected representatives of PRIs and 24.4 percent are social workers. The ANM of the sub centre should also be the member of VHSNC of the village falling under the sub centre. Table 2 reveals that in district Firozpur and Mansa four VHSNC each does not have ANM as member of the committee. The purpose of having ANM as member of committee is to prepare village health plan. One could envisage the status of health plans prepared by the VHSNC in these districts.

\section{PROFILE OF THE MEMBERS}

This section deals with the profile of the respondents and covers their gender, age, caste and education wise distribution.

Majority of the members of the sampled committees in all the districts were females which is a good indicator as females are in a better position to make a plan for the health needs and coordination with ANM/ASHAs. District Mansa was an exception where male outnumbered the female members (Table 3). About one third members of the VHSNCs in Punjab were in the age group of 20-40 years and 12 percent of the total members of VHSNCs were above 60 years. While one half of the total members of VHSNCs were falling in the age group of 40-60 years.

The instructions for nominating members clearly indicate that the members to be nominated must belong to either scheduled caste, backward class or other marginalised groups. The data from the filed survey points a totally different 

belonged to General Category whereas the other half of the members belonged to either Scheduled caste or Backward Class category.

Educational levels of the committee members is an important indicator of the functioning of committee as higher the educational level better will be the understanding of the workings of committee. The data on this indicator reveals that about ten per cent members were illiterate in Punjab and about twenty per cent were educated upto matriculation and on a positive note, a majority of members of VHSNCs in Punjab were graduates (Table 3).

Table 3: Profile of VHSNC Members.

\begin{tabular}{llllll}
\hline Profile Indicators & $\begin{array}{l}\text { Districts } \\
\text { Mansa }\end{array}$ & Gurdaspur & Firozpur & Mohali & Total \\
\hline Sex & & & & & \\
Male & 165 & 126 & 144 & 74 & 509 \\
Female & 99 & 210 & 184 & 215 & 708 \\
Age & & & & & \\
20-40 years & 111 & 95 & 145 & 88 & 439 \\
$40-60$ years & 124 & 180 & 155 & 176 & 635 \\
$>60$ years & 29 & 61 & 28 & 25 & 143 \\
Caste & & & & & \\
General & 154 & 151 & 147 & 127 & 579 \\
SC & 96 & 143 & 130 & 106 & 475 \\
BC & 14 & 42 & 51 & 56 & 163 \\
Education & & & & & \\
Illiterate & 45 & 20 & 45 & 10 & 120 \\
Upto Primary & 3 & 1 & - & 1 & 5 \\
Upto Matric & 40 & 71 & 60 & 66 & 237 \\
Upto Graduation & 135 & 211 & 183 & 179 & 708 \\
Above Graduation & 41 & 33 & 40 & 33 & 147 \\
\hline
\end{tabular}

\subsection{Profile of Chairperson}

The instructions of the Committee formation states that the Chairperson of the VHSNC should be a woman elected member of the gram panchayat (panch) preferably from among the SC/ST communities, who is a resident of that 
village. If there is no woman panch from that village, then preference should be given to any panch from the SC/ST. Table 4 on the profile of chairperson revealed that 14 per cent of the total chairpersons were males; nine were in district Gurdaspur and five in district Firozpur. The data further revealed that in 53 per cent of VHSNC the Chairpersons belonged to General Caste while 39 per cent of them belonged to the Backward Caste.

Chairpersons of 27 per cent of the VHSNCs in Punjab were in the age group of 20-40 years. In district Firozpur 11 of 25 chairpersons of the VHSNCs were young i.e. in the age group of 20-40 years. This was followed by district Mohali ( 9 out of 25).

One-fourth of the chairpersons of the VHSNCs in Punjab were illiterate while nearly one half of the chairpersons of the VHSNCs in Punjab had educational level below matriculation. About one third chairpersons of the VHSNCs in Punjab reported their educational level above matriculation. Only a few (three per cent) had education above graduation.

It is pertinent to mention that in district Mansa about seven out of every ten Chairpersons of the VHSNCs were illiterate and among the 25 chairpersons of the VHSNCs in district Mansa only one chairperson was above matriculation (Table 4).

Table 4: Profile of Chairpersons of VHSNCs.

\begin{tabular}{llllll}
\hline Profile Indicators & $\begin{array}{l}\text { Districts } \\
\text { Mansa }\end{array}$ & Gurdaspur & Firozpur & Mohali & Total \\
\hline Sex & & & & & \\
\hline Male & - & 9 & 5 & - & 14 \\
Female & 25 & 16 & 20 & 25 & 86 \\
Caste & & & & & \\
Gen & 9 & 10 & 8 & 12 & 39 \\
SC & 16 & 12 & 13 & 12 & 53 \\
BC & - & 3 & 4 & 1 & 8 \\
Age & & & & & \\
$20-40$ & 5 & 2 & 11 & 9 & 27 \\
$40-50$ & 14 & 20 & 11 & 15 & 42 \\
$>60$ & 6 & 3 & 3 & 1 & 13 \\
\hline Education & & & & & \\
\hline Illiterate & 17 & 2 & 5 & 1 & 25 \\
& & & & & \\
\hline
\end{tabular}

Functioning of Village Health

Sanitation and Nutrition

Committees in Punjab: An

Appraisal 


\begin{tabular}{lllllll} 
Ahmed, SI & Upto Primary & 1 & - & - & - & 1 \\
Upto Matric & 6 & 11 & 13 & 13 & 44 \\
Upto Graduation & 1 & 10 & 6 & 10 & 27 \\
Above Graduation & - & 2 & 1 & 1 & 3 \\
\hline
\end{tabular}

\subsection{Profile of Member Secretary}

As per the new guidelines of VHSNCs, ASHA worker should be designated Member Secretary of the VHSNC. The data from the field survey indicated that of the 25 VHSNCs in district Gurdaspur only 18 have ASHA as member secretary while in district Mansa 22 out of 25 VHSNCs have ASHA as member secretary. In districts Firozpur and Mohali ASHA was designated member secretary in all the sampled VHSNCs (Table 5).

Table 5: VHSNCs Member Secretary Designated.

\begin{tabular}{lccc}
\hline District & ANM & ASHA Worker & Anganwari Worker \\
\hline Mansa & 3 & 22 & - \\
Gurdaspur & 4 & 18 & 3 \\
Firozpur & - & 25 & - \\
Mohali & - & 25 & - \\
\hline
\end{tabular}

In case of district Mansa ANM was member secretary of three VHSNCs whereas in district Gurdaspur ANM was member secretary in four VHSNCs and AWW was member secretary of three VHSNCs. The data from the field survey thus indicates that in ten percent of the sampled VHSNCs new guidelines were not followed till the time of survey.

The data regarding the profile of Member Secretary reveals that a Majority of member secretaries of the sampled VHSNCs in Punjab belonged to SC community and about one third of them belonged to the general category (Table 6). As far as age is concerned the data revealed that about three-fifths of the Member Secretaries of the sampled VHSNCs in Punjab were below 40 years of age and 13 per cent were above 50 years.

Educational level of the member secretaries of the sampled VHSNCs in Punjab was observed satisfactory with about seven out of ten member secretaries had education levels above matriculation. On the other hand more than one-fifth of the member secretaries of the sampled VHSNCs in Punjab were not even educated upto matriculation (Table 6). 
Table 6: Profile of Member Secretary of VHSNCs.

\section{Districts}

Profile Indicators

\section{Mansa Gurdaspur Firozpur Mohali}

Caste

Gen

$\mathrm{SC}$

$\mathrm{BC}$

Age

$20-40$

$40-50$

$50-60$

Education

Below Matriculation

Matriculation to

Graduation

Above Graduation
11

12

2

15

5

5

11

12

2

10

8

7

5

16

7

14

4

34

4

19

14

11

58

5

1

Total

$7 \quad 1$

17

1

21

5

25

16

22

74

\section{FUNCTIONING OF VHSNCS IN PUNJAB}

This section deals with the preparation of village health plan, VHSNC record maintenance, birth and death records, bank accounts and cash book of VHSNC.

\subsection{Preparation of Village Health Plan}

One of the major activities of VHSNC is to prepare a village health plan. Thus information on this aspect was collected during the field survey. The data however gave a dismal picture as only 23 per cent of the VHSNCs claimed to have prepared the village health plan with percentage ranging from 40 per cent in Mansa, 28 per cent in Mohali district and 12 per cent each in Gurdaspur and Firozpur districts indicative of a positive response (Table 7).

Table 7: Preparation of Village Health Plan by VHSNCs.

\begin{tabular}{llll}
\hline District & Yes & No & Total \\
\hline Mansa & 10 & 15 & 25 \\
Gurdaspur & 3 & 22 & 25 \\
Firozpur & 3 & 22 & 25 \\
Mohali & 7 & 18 & 25 \\
\hline
\end{tabular}


Formation of Village Health Plan is important and a positive step which could lead to improving nutritional and health status of the village population especially women and children. Alongwith with this it is equally important to note as to who all were involved in preparation of the health plan. The data on this aspect was collected from only those who prepared the village health plan.

The data on this aspect revealed that in little less than three-fourths of the cases village health plans were prepared by the committee and in the remaining cases the plan was prepared by either ASHA or ANM (Table 8).

Table 8: Village Health Plan Prepared By.

\begin{tabular}{llll}
\hline District & Committee & ASHA/ANM & Total \\
\hline Mansa & 10 & - & 10 \\
Gurdaspur & - & 3 & 3 \\
Firozpur & 1 & 2 & 3 \\
Mohali & 6 & 1 & 7 \\
\hline
\end{tabular}

Reasons for not preparing health plans were asked from those VHSNCs who had not prepared village health plan. Surprisingly, 96 per cent of them were not aware about the mandate of preparing village health plan (Table 9). A few of them (about 4 per cent) also reported that although they were aware of the mandate of preparing village health plan but the plan was not prepared due to non-cooperation of members and lack of consent on the issues among the VHSNCs members. Among them, two VHSNCs were in Firozpur while one was in Mohali district.

Table 9: Reasons for not Preparing Village Health Plan

\begin{tabular}{llll}
\hline District & Lack of Awareness & Non Cooperation of Members & Total \\
\hline Mansa & 15 & - & 15 \\
Gurdaspur & 22 & - & 22 \\
Firozpur & 20 & 2 & 22 \\
Mohali & 17 & 1 & 18 \\
\hline
\end{tabular}

\subsection{VHSNC Record Maintenance}

Record keeping and maintenance is an important to keep a track on the activities of the VHSNCs. The data on this aspect was collected and Table 10 indicates that records of village health plan were mainly kept by ASHA workers in Mansa, Firozpur and Mohali districts. While in case of Gurdaspur 
district records of village health plan were kept by ASHA workers in 36 per cent of the cases followed by sarpanch in 32 per cent cases, and 16 per cent each by ANM and chairperson.

The record-keeping of births and deaths is responsibility of VHSNC. It was therefore imperative to assess this to have a comprehensive view of functioning of VHSNCs.

Table 10: Records of Village Health Plan Kept By.

\begin{tabular}{lllll}
\hline District & ASHA Worker & ANM & Sarpanch & Chairperson \\
\hline Mansa & 24 & 1 & - & - \\
Gurdaspur & 9 & 4 & 8 & 4 \\
Firozpur & 24 & - & 1 & - \\
Mohali & 25 & - & - & - \\
\hline
\end{tabular}

All the covered VHSNC were enquired about maintenance of these registers. The data reveals that in Mansa and Firozpur districts, both the birth and death registers were maintained by all the covered VHSNCs. In Mohali district, 84 per cent of the VHSNCs maintain death registers while birth registers were maintained by 88 per cent of the committees respectively. Among the four districts, the maintenance of death and birth registers was lowest in Gurdaspur district (68\% each in case of birth and death registers) (Fig 1).

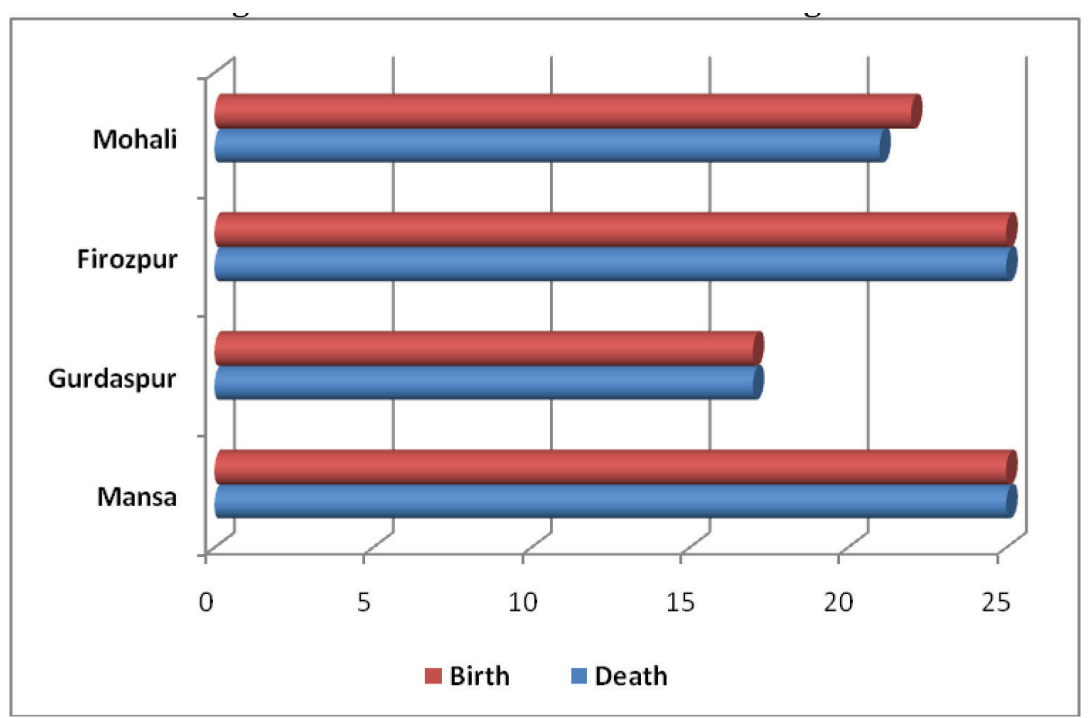

Figure 1: VHSNC with Death and Birth Register. 
It is mandatory that all VHSNCs should have a bank account, to which the untied fund of the VHSNC can be credited. The data on this aspect was collected and the field survey indicated that all the covered VHSNCs had an operational bank account (Table 11). However, further it was revealed that 8 per cent of the VHSNCs in Mohali and 36 per cent of them in Gurdaspur did not possess passbook of the bank account opened for this purpose.

Table 11: VHSNC with Bank Accounts and its Passbook.

\begin{tabular}{lll}
\hline District & Bank Account & Passbook \\
\hline Mansa & 25 & 25 \\
Gurdaspur & 25 & 16 \\
Firozpur & 25 & 25 \\
Mohali & 25 & 23 \\
\hline
\end{tabular}

All the 11 cases that were not having the bank passbook were further enquired about the reasons of not keeping them. All the VHSNCs in Gurdaspur district claimed that they were not given any passbooks by their respective banks. The withdrawal of money is done via cheque and they did not face any problem in the process. In Mohali district both the VHSNCs were not aware about keeping bank passbooks with them (Table 12).

Table 12: Reasons for not Keeping Bank Passbook.

\begin{tabular}{lll}
\hline District & Not given by bank & Not aware \\
\hline Mansa & - & \\
Gurdaspur & 9 & - \\
Firozpur & - & 2 \\
Mohali & & 2 \\
\hline
\end{tabular}

Proper maintenance of the cash book of the VHSNC is imperative for recording of income and expenditure of the committee. This cash book is to be maintained by the VHSNC Member Secretary cum Convener (ASHA) with the help of AWW/ANM/Chairperson of VHSNC. The data on this aspect revealed that the maintenance of cash book by VHSNCs was not up to the mark as it was not maintained as ought to be. This cash book was maintained by 88 per cent of the VHSNCs in Mansa, 72 per cent in Mohali, 56 per cent in Firozpur followed by 52 per cent in Gurdaspur district. Overall, cash book was absent in one-third of the VHSNCs (Table 13). 
Table 13: VHSNCs with Cash Book.

\begin{tabular}{llll}
\hline District & Yes & No & Total \\
\hline Mansa & 22 & 3 & 25 \\
Gurdaspur & 13 & 12 & 25 \\
Firozpur & 14 & 11 & 25 \\
Mohali & 18 & 7 & 25 \\
\hline
\end{tabular}

Functioning of Village Health Sanitation and Nutrition Committees in Punjab: An

Appraisal

The 33 VHSNCs not keeping the cash book were probed further about the reasons of not keeping it. All of them claimed that they were not aware that they had to maintain a cash book for smooth functioning of VHSNC (Fig 2).

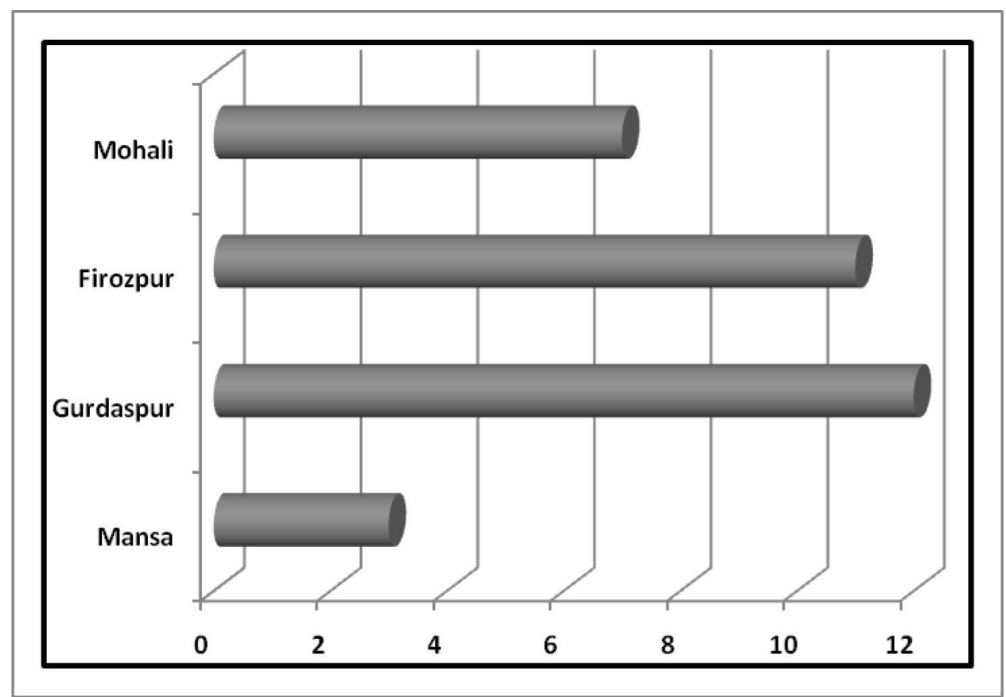

Figure 2: VHSNCs Not Aware to Keep Cash Book.

\section{MEETINGS OF VHSNCS}

It is mandatory to hold meetings of VHSNC at least once every month. Fixing a particular date for meeting in each month such as $5^{\text {th }}$ of every month or first Saturday of every month helps to ensure attendance of each member. It helps in better functioning of VHSNC in a coordinated manner. However, the field survey indicates that this norm was not followed in a little less than one-half of the VHSNCs.

Meetings were organized on monthly basis in 72 per cent VHSNC in Mohali, 64 per cent in Firozpur, 44 per cent in Gurdaspur and 40 per cent in Mansa district. In other VHSNCs timing of conducting VHSNC meetings was not fixed (Fig 3). 
Ahmed, SI

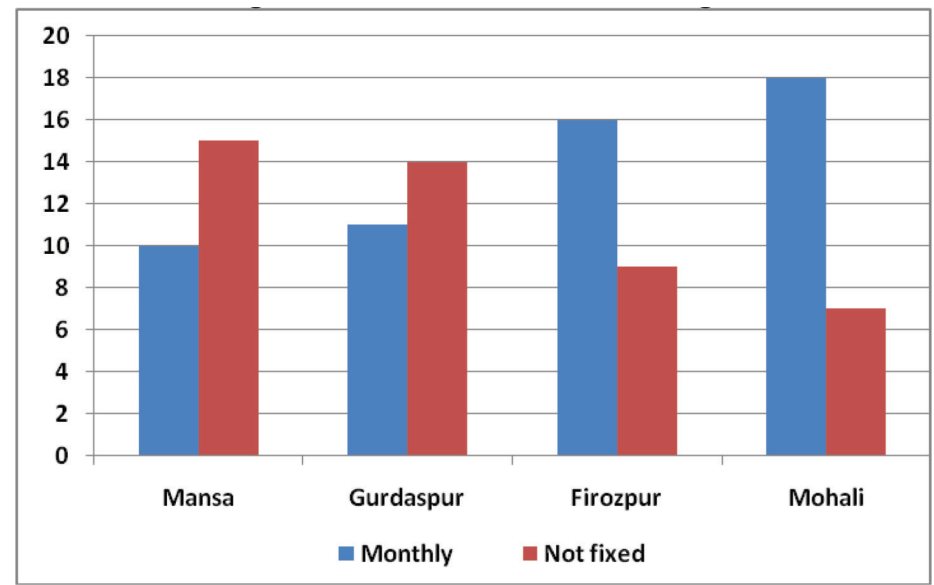

Figure 3: Schedule of VHSNCs Meetings.

Public place such as AWC, Panchayat Bhawan or school which is easily accessible must be preferred place for holding meetings. It should also be ensured that there is no change in the venue of the meetings. Information regarding the place of meeting was collected and the data indicates that in 53 per cent of VHSNCs the meetings were held in anganwari centre, while in onethird of the cases it was held in the health centre. In a few cases the meetings were also held in school (3\%), sarpanch house (2\%) and panchayat ghar (1\%). In 14 per cent VHSNCs, meetings were organized at other places including dharamshala or other common places of the village (Table 14).

Table 14: Place of VHSNCs Meeting Organized.

\begin{tabular}{lllll}
\hline District & Mansa & Gurdaspur & Firozpur & Mohali \\
\hline Panchayat Ghar & - & - & 1 & - \\
Aanganwari Centre & 12 & 13 & 9 & 19 \\
Health Centre & 8 & 5 & 7 & 5 \\
School & - & 1 & 2 & - \\
Sarpanch s house & - & 1 & 1 & - \\
Any other place & 5 & 5 & 3 & 1 \\
Total & 25 & 25 & 25 & 25 \\
\hline
\end{tabular}

Data was collected regarding the number of meetings held and total members attended these meetings in last six months. The numbers of meetings and total members attended these meetings were then tabulated. Among all the districts, 
the number of meetings held were highest in Firozpur (93) followed by Mohali (82), Mansa (57) and Gurdaspur district (51). If regular monthly VHSNC meetings were held in each VHSNC then total for each district would ideally come to be 150 meetings and total comes to 600 meetings.

Field level data of the present study indicates that only half of the expected meetings were held. In district Mansa and Gurdaspur about two meetings were organised every six months (Table 15). On an average about 9 members attended meetings of VHSNs in Punjab indicating that large number of members was not attending the meetings organised by VHSNCs in Punjab. On positive note it was observed that proceedings of all meetings were recorded.

Table 15: Number of VHSNC Meetings held and Total Members attended Meetings (in last six months).

\begin{tabular}{lll}
\hline District & Number of Meetings held & Total Members attended Meetings \\
\hline Mansa & 57 & 491 \\
Gurdaspur & 51 & 353 \\
Firozpur & 93 & 910 \\
Mohali & 82 & 894 \\
Total & $\mathbf{2 8 3}$ & $\mathbf{2 6 4 8}$ \\
\hline
\end{tabular}

Fig 4 indicates that the number of VHSNCs where no meeting was held in last six months. This number was as high as 40 per cent in Mansa, 32

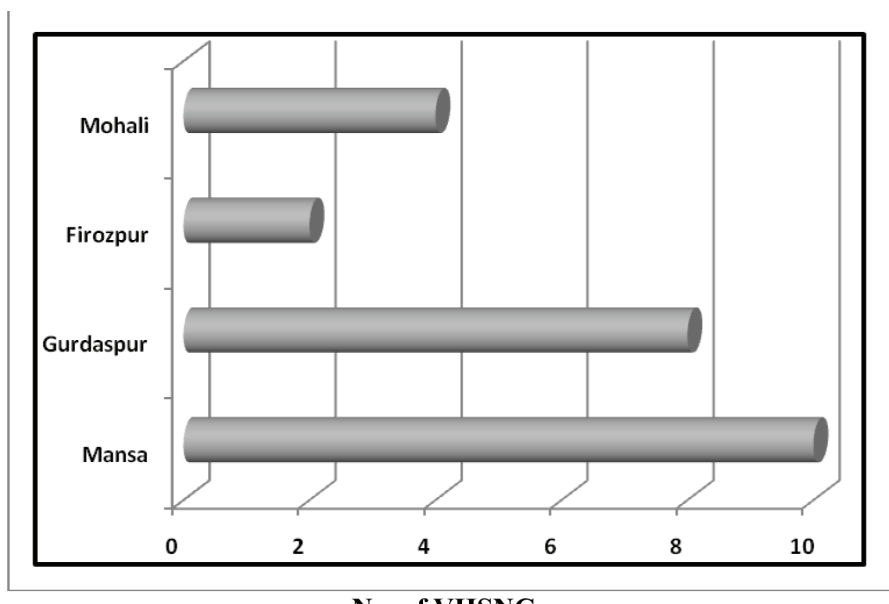

No. of VHSNCs

Figure 4: VHSNCs Meeting Not Held (in last six months). 

district reported that no VHSNC meeting was held in last six months. Overall, 24 per cent VHSNCs in Punjab had not conducted this meeting in last six months.

Mere holding meeting is not sufficient but equally important is to know the issues discussed in the meeting. Respondents were asked about the major issues being discussed in these VHSNC meetings. Generally, one issue was discussed during each meeting of VHSNC in Punjab. The main issues discussed in various VHSNCs meetings in Punjab were health (including mother and child health), environment and hygiene (56\%) followed by utilization of funds (27\%), medicines and ORS (8\%), ASHA incentive (4\%) and furniture and health equipments (4\%).

Table 16: Major Issues Discussed during VHSNCs Meetings.

\begin{tabular}{lllll}
\hline Major issues discussed & $\begin{array}{l}\text { District } \\
\text { Mansa }\end{array}$ & Gurdaspur & Firozpur & Mohali \\
\hline Utilize fund & 15 & 17 & 23 & 21 \\
$\begin{array}{l}\text { Health, Environment and } \\
\text { Hygiene Issues }\end{array}$ & 35 & 28 & 60 & 35 \\
$\begin{array}{l}\text { Medicines, ORS etc. } \\
\text { Drug awareness }\end{array}$ & 5 & 5 & 4 & 9 \\
Midday meal & 2 & - & - & 2 \\
$\begin{array}{l}\text { ASHA incentive } \\
\text { Purchase of Furniture and }\end{array}$ & - & 1 & - & - \\
health equipments & - & - & 4 & 8 \\
Total & $\mathbf{5 7}$ & $\mathbf{5 1}$ & $\mathbf{9 3}$ & 8 \\
\hline
\end{tabular}

\section{Funds for VHSNC}

Each VHSNC is entitled to an annual untied grant of Rs.10,000 from the National Health Mission (NHM). The untied grant is a resource for community action at the local level. Nutrition, Education \& Sanitation, Environmental Protection, Public Health Measures are key areas where these funds could be utilized.

State NHM release the fund to district after receiving the statement of unutilized funds with VHSNCs at the end of financial year in the respective districts. Taking into consideration the State NHM release the untied fund after deducting the unspent amount. Table 17 revealed that in the year 2015-16 
Rs 6,82,87,000 were released instead of Rs 12,95,60,000 for all the VHSNCs in Punjab. It clearly indicates that nearly one half of the amount released in year 2014-15 remained unspent. The districts further allocate the funds to blocks as per the utilization submitted by the blocks. At block level the untied fund has been distributed equally among all the VHSNCs without taking into consideration the utilization certificate submitted by the VHSNC. Hence, no VHSNC in Punjab received Rs 10,000 in 2015-16.

VHSNCs in district Mohali, Gurdaspur, Mansa and Firozpur received 4580, 5528, 5755 and 6658 rupees in 2015-16 respectively (Table 18). It was very difficult to meet out the expenditure of VHSNCs in such a meagre amount. At block level the accounts department should disburse the fund as per the statement of balance submitted by VHSNCs individually.

Table 17: Funds Released to VHSNCs in Punjab (in Rs lakhs).

\begin{tabular}{|c|c|c|c|c|c|}
\hline Districts & $\begin{array}{l}\text { Amount } \\
\text { released } \\
2014-15\end{array}$ & $\begin{array}{l}2014-15 \\
\text { Amount } \\
\text { Released per } \\
\text { VHSNC }\end{array}$ & $\begin{array}{l}\text { Amount } \\
\text { released } \\
2015-16\end{array}$ & $\begin{array}{l}2015-16 \\
\text { Amount } \\
\text { Released Per } \\
\text { VHSNC } \\
\end{array}$ & $\begin{array}{l}\text { No. of } \\
\text { VHSNC }\end{array}$ \\
\hline Amritsar & 81.28 & 9888 & 29.23 & 3556 & 822 \\
\hline Barnala & 18.43 & 11591 & 0.45 & 283 & 159 \\
\hline Bathinda & 23.55 & 7903 & 18.46 & 6195 & 298 \\
\hline Faridkot & 23.38 & 12503 & 0.00 & 0 & 187 \\
\hline Fatehgarh & 30.19 & 6940 & 24.25 & 5575 & 435 \\
\hline Fazilka & 46.63 & 12501 & 11.02 & 2954 & 373 \\
\hline Firozpur & 60.44 & 7416 & 52.95 & 6497 & 815 \\
\hline Gurdaspur & 95.14 & 7369 & 102.80 & 7963 & 1291 \\
\hline Hoshiarpur & 174.03 & 12273 & 63.85 & 4503 & 1418 \\
\hline Jalandhar & 88.73 & 9719 & 33.76 & 3698 & 913 \\
\hline Kapurthala & 57.48 & 10191 & 17.63 & 3126 & 564 \\
\hline Ludhiana & 114.05 & 12356 & 30.39 & 3293 & 923 \\
\hline Mansa & 17.33 & 7312 & 16.13 & 6806 & 237 \\
\hline Moga & 21.59 & 6726 & 15.50 & 4829 & 321 \\
\hline Mohali & 28.46 & 7509 & 19.23 & 5074 & 379 \\
\hline Muktsar & 26.70 & 10000 & 1.17 & 438 & 267 \\
\hline Nawanshahar & 56.00 & 11991 & 7.57 & 1621 & 467 \\
\hline Pathankot & 30.85 & 7310 & 53.52 & 12682 & 422 \\
\hline
\end{tabular}

Functioning of Village Health Sanitation and Nutrition Committees in Punjab: An

Appraisal

\section{$\longrightarrow$}


Ahmed, SI

\begin{tabular}{|c|c|c|c|c|c|}
\hline Patiala & 69.29 & 7325 & 70.77 & 7481 & 946 \\
\hline Ropar & 76.51 & 12709 & 50.77 & 8434 & 602 \\
\hline Sangrur & 68.66 & 11818 & 3.64 & 627 & 581 \\
\hline Taran Taran & 39.55 & 7379 & 59.77 & 11151 & 536 \\
\hline Total & 1248.25 & 9635 & 682.87 & 5271 & 12956 \\
\hline \multicolumn{6}{|c|}{ Source: Mission Director NHM, Punjab } \\
\hline District & \multicolumn{2}{|c|}{ Total Amount (in Rs) } & \multicolumn{3}{|c|}{ Amount Per VHSNC (in Rs) } \\
\hline Mansa & \multicolumn{2}{|c|}{143879} & \multicolumn{3}{|c|}{5755} \\
\hline Gurdaspur & \multicolumn{2}{|c|}{138212} & \multicolumn{3}{|c|}{5528} \\
\hline Firozpur & \multicolumn{2}{|c|}{166450} & \multicolumn{3}{|c|}{6658} \\
\hline Mohali & \multicolumn{2}{|c|}{114500} & \multicolumn{3}{|c|}{4580} \\
\hline
\end{tabular}

When asked about the balance in bank account, 13 VHSNC reported that they do not have any money in their account, 25 VHSNC reported less than 500 rupees balance in their account and 58 VHSNC were having balance between 500 to 2000 rupees in their account. Only one VHSNC in district Firozpur had more than 4000 rupees in its bank account at the time of survey (Table 19).

Table 19: VHSNCs having Balance amount in Bank Account (in Rs).

\begin{tabular}{llllllll}
\hline District & Nil & $<\mathbf{5 0 0}$ & $\mathbf{5 0 0}-\mathbf{1 0 0 0}$ & $\mathbf{1 0 0 0}-\mathbf{2 0 0 0}$ & $\mathbf{2 0 0 0}-\mathbf{4 0 0 0}$ & $\mathbf{4 0 0 0}>$ & Total \\
\hline Mansa & 1 & 6 & 10 & 8 & - & - & 25 \\
Gurdaspur & 6 & 14 & 2 & 3 & - & - & 25 \\
Firozpur & 4 & 4 & 7 & 8 & 1 & 1 & 25 \\
Mohali & 2 & 1 & 10 & 10 & 2 & - & 25 \\
Total & 13 & 25 & 29 & 29 & 3 & 1 & 100 \\
\hline
\end{tabular}

It was also enquired about the VHSNC have any cash in hand at the time of survey. 80 out of 100 VHSNCs reported that the do not have any money in hand (Table 20). Among the remaining $20 \mathrm{VHSNCs}, 8 \mathrm{VHSNCs}$ were having less than five hundred rupees in hand, 4 VHSNCs were having $500-1000$ rupees in hand, 3 VHSNCs were having 1000 - 2000 rupees in hand and 5 VHSNCs were having 2000 - 4000 rupees in hand. 
Table 20: VHSNCs having Cash in Hand (in Rs).

\begin{tabular}{lllllll}
\hline District & Nil & $\mathbf{< 5 0 0}$ & $\mathbf{5 0 0 - 1 0 0 0}$ & $\mathbf{1 0 0 0}-\mathbf{2 0 0 0}$ & $\mathbf{2 0 0 0}-\mathbf{4 0 0 0}$ & Total \\
\hline Mansa & 22 & 3 & - & - & - & 25 \\
Gurdaspur & 21 & 2 & 1 & 1 & - & 25 \\
Firozpur & 17 & 3 & 1 & 1 & 3 & 25 \\
Mohali & 20 & - & 2 & 1 & 2 & 25 \\
Total & 80 & 8 & 4 & 3 & 5 & 100 \\
\hline
\end{tabular}

\subsection{Utilization of Funds}

It is important that decisions on expenditure should be taken in the VHSNC. In special circumstances the district could give a direction or a suggestion to all VHSNCs to spend on a particular activity- but even then it should be approved first by the VHSNC. VHSNCs will not be directed to contract with specific service providers for specific activities, regardless of the nature of the activity. All payments from the untied grant must be done through the VHSNCs. VHSNC fund should preferably be not used for works or activities for which an allocation of funds is available through PRI or other departments.

The member secretary should be allowed to spend small amounts on necessary and urgent activities, of total up to Rs. 1000, for which details of activity and bills and vouchers should be submitted in the next VHSNC meeting and approval of the committee taken. Although, every village is encouraged to contribute additional funds to the Village Health, Sanitation and Nutrition Committee but no such case of support in terms of cash was reported during the survey. However, few panchyats and villagers supported in kind at the time of repairs and construction works.

Majority of the funds received by VHSNCs was utilized for sanitation and cleanliness of the village. In all, about 80 percent of the VHSNCs reported that they had spent on the cleanliness of village streets, spray on the bushes and unwanted grass and vegetation, spray on water pools and village ponds etc. Only two VHSNCs in district Gurdaspur reported that they purchased sports equipments for village youth from the fund they received (Table 21). One VHSNC in district Gurdaspur organised drug awareness camp in the village by utilizing untied fund of VHSNC.

Funds were also utilized to purchase furniture for anganwari centre and EPI day rooms allotted by village to the health staff. In district Mansa seven VHSNCs spent on repair and construction work of sub centre/health centre. Apart from this untied fund was also utilized for purchasing medicines and
Functioning of Village Health

Sanitation and Nutrition

Committees in Punjab: An

Appraisal 
Table 21: Utilization of Funds by VHSNCs in 2015-16.

\begin{tabular}{lllll}
\hline District & Mansa & Gurdaspur & Firozpur & Mohali \\
\hline Village sanitation and cleanliness & 18 & 23 & 22 & 18 \\
$\begin{array}{l}\text { Purchase of electric / sports } \\
\text { equipments }\end{array}$ & 2 & 2 & - & - \\
Furniture & 2 & 1 & 3 & 8 \\
Sub centre construction/repair & 7 & - & - & - \\
Stationary & 4 & & 2 & 5 \\
Honorarium to ASHA & - & - & 1 & 6 \\
Medicines & - & 1 & 3 & 2 \\
Drug Awareness camp & - & 1 & - & - \\
\hline Multiple responses received & & & &
\end{tabular}

stationary etc. Honorarium to ASHA for organising meetings of VHSNCs was also given from the funds by VHSNCs.

Decisions taken on expenditure should be documented in the minutes. It is preferably adopted as a written resolution that is read out and then incorporated into the minutes in a meeting where there was adequate quorum. All VHSNCs in Punjab were found following this instruction regarding the utilization of fund.

\section{FUNCTIONING OF VHSNCS IN PUNJAB: ISSUES EMERGED}

As per the revised guidelines of VHSNCs since 2013, ASHAs have replaced ANMs as member secretary of VHSNCs in Punjab. Although the ASHAs were formally trained to fulfil the duties as member secretary by the State NHM directorate, however, it was observed that they were not much aware about duties of member secretary and functioning of VHSNCs.

ASHAs designated as member secretary reported that members of VHSNCs generally do not cooperate in implementation of any plan/programme of VHSNC. They also brought forth that despite making repeated calls reminders various members of the VHSNC did not attend the scheduled meetings. Although majority of chairpersons of VHSNCs are female panchayat members but it was their husbands who were the main decision makers. Female panchayat members do not participate actively. Often the meetings were attended by the husband of female panchayat members.

In some villages ASHAs designated as member secretary reported that even ANMs were not cooperating as the latter felt that responsibility of member secretary has been taken from them and given to ASHAs. 
ASHAs being recommended by sarpanch do not have much say in village panchayat and usually follow the directions of sarpanch. In some cases it was observed that sarpanch took the untied fund amount from ASHA and spent it according to their own requirements. ASHAs had to struggle a lot to get the receipts and maintain records of the expenditure. In one village the researcher found that weighing scale was purchased by the sarpanch from the VHSNC fund, bill was submitted but weighing scale was not handed over to ASHA. Sarpanch handed over the machine to ASHA after researcher intervened.

Lack of monitoring was found the main hindrance in functioning of VHSNCs in Punjab.

\section{VHSNC IN PUNJAB: MEMBERS VIEWS}

During the fieldwork, discussions with members of VHSNCs were also carried out. Majority of members were not aware about the components and objectives of VHSNC. The only aspect they were aware of was that these committees were formed to spend untied funds given for village sanitation and cleaning. Many of them were not even aware about utilization of fund by VHSNC in their respective villages during the last year. Very few members reported that they attended the training given to the members of VHSNCs organised by health department. As usual many female members reported that their husbands attend the training. All members reported that the untied fund is always helpful in solving the issues and problems of the village and the amount of untied fund given to VHSNCs should be increased.

\section{RECOMMENDATIONS AND SUGGESTIONS}

- Regular and timely monitoring can improve the functioning of VHSNCs in Punjab. ASHA facilitator should be trained and made responsible for monitoring the VHSNCs. At block level BEE should be designated nodal officers.

- Young villagers should be motivated to become members of VHSNCs.

- It should be mandatory for VHSNCs to prepare village health plan and copy of village health plan prepared should be submitted at block level to BEE.

- Disbursal of funds should be made in the beginning of the financial year not later than the month of July. If fund is made available during the end of financial year i.e. in the month of February and March it becomes difficult for many VHSNCs to utilize it before 31 March and mounting of the unspent amount leads to cut in the disbursal of the next year fund.
Functioning of Village Health

Sanitation and Nutrition

Committees in Punjab: An

Appraisal 
Ahmed, SI $\quad-$ Utilization certificate should be submitted by the month of December. So that district and block official can give directions to the VHSNCs for non utilization of funds if any.

- The amount of untied fund should be increased. Rs 10,000 were sanctioned at the initiation of NHM in 2005. No revision or enhancement in the untied fund has been made ever since the initiation of the programme.

- The fund should be proportionate to the size of population of the respective village. As some villages in Punjab have considerably large size of population.

\section{ACKNOWLEDGEMENT}

This study was carried out under Annual Work Plan 2016-17 submitted by Population Research Centre at CRRID to Ministry of Health and Family Welfare, New Delhi. Author thankfully acknowledges the support provided by Ministry for field work and data collection. Author is also grateful to the health staff posted at district and village level health centres and ASHAs for the support provided by them during the field survey.

\section{REFERENCES}

[1] Sah Pramod Kumar et al (2013) "Performance of Village Health, Nutrition and Sanitation Committee: A Qualitative Study from Rural Wardha, Maharashtra', The Health Agenda, Vol. 1, No. 4.

[2] Semwal V et al (2013) "Assessment of Village Health Sanitation and Nutrition Committee Under NRHM in Nainital District Of Uttarakhand", Indian Journal of Community Health, Vol. 25, No 4.

[3] Srivastava et. al. (2016) "Are Village Health Sanitation and Nutrition Committees Fulfilling their Roles for Decentralised Health Planning and Action? A Mixed Methods Study From Rural Eastern India", Bio Medical Central, Public Health,16:59, https://bmcpublichealth.biomedcentral.com/articles www.pbnrhm. org 